\title{
Standarisasi Halal Majelis Ulama Indonesia dalam penyembelihan Ayam di Desa Kertawinangun Cirebon
}

\author{
Afif Muamar, Juju Jumena \\ IAIN Syekh Nurjati Cirebon \\ afifmuamar85@gmail.com dan jumena72@yahoo.com
}

\begin{abstract}
This study aims to determine the process of slaughtering broilers in the village of Kertawinangun and its comformity to the the Indonesian Ulema Council standard. This research is descriptive-analytical using qualitative methods. It resulted in two things, first, the method of slaughtering and processing stages of broilers grouped into three stages, namely the stages in the preparation of chickens, slaughtering, and processing of chickens. And secondly, several factors influence consumer behavior related to halal slaughter, namely; 1) Cultural Factors, namely human behavior is largely determined by the culture that surrounds it, and its influence will always change every time by the times. 2) Social factors include family groups and role models. 3) Personal factors consist of age and stages of the life cycle, economic conditions, lifestyle, and personality.
\end{abstract}

Keywords: Halal Standardization, Animal Slaughter, and the Indonesian Ulema Council.

\begin{abstract}
Abstrak
Penelitian ini bertujuan untuk mengetahui proses penyembelihan ayam potong di Desa Kertawinangun dan proses penyembelihan yang sesuai standarisasi Majelis Ulama Indonesia.Penelitian ini bersifat deskriptif-analitis dengan menggunakan metode kualitatif. Penelitian ini menghasilkan dua hal, yaitu pertama, cara pemotongan dan tahapan pengolahan ayam potong dikelompokan dalam tiga tahapan, yaitu tahapan dalam persiapan ayam, penyembelihan, dan pengolahan ayam. Dan kedua, terdapat beberapa faktor yang mempengaruhi perilaku konsumen terkait dengan penyembelihan secara halal, yaitu; 1) Faktor Kebudayaan, yaitu perilaku manusia sangat ditentukan oleh kebudayaan yang melingkupinya, dan pengaruhnya akan selalu berubah setiap waktu sesuai dengan
\end{abstract}


kemajuan zaman. 2) Faktor Sosial yang meliputi kelompok keluarga dan panutan. 3) Faktor Pribadi yang terdiri dari umur dan tahapan siklus kehidupan, keadaan ekonomi, gaya hidup dan kepribadian.

Kata Kunci: Standarisasi Halal, PenyembelihanHewan, dan Majelis Ulama Indonesia.

\section{Pendahuluan}

Untuk kelangsungan hidup manusia, makanan merupakan kebutuhan pokok dan kebutuhan biologis setiap insan disamping minum. Allah Subhanahu wa Taala zat yang Maha Agung lagi Maha Tinggi memperkenankan kepada hamba-Nya untuk menikmati segala rezeki yang baik (at-thayyibah) dan mengharamkan yang buruk (al-khabi's) seperti bangkai, darah, babi dan lain-lain. Islam telah mengatur cara untuk memenuhi kebutuhan pangan, dimana ada pangan yang dihalalkan dan ada pula pangan yang diharamkan. Bahan pangan yang dibutuhkan oleh tubuh manusia untuk memenuhi kebutuhan sehari-hari, salah satunya protein yang bisa diperoleh dari ikan dan daging hewan. Islam mempunyai garis tegas yang menyatakan bahwa diharamkan memakan hewan halal tanpa disembelih secara syara' terlebih dahulu (Hadi 1997).

Daging merupakan kebutuhan pokok yang dikonsumsi hampir oleh seluruh masyarakat Indonesia, karena daging merupakan sumber protein. Daging mengandung sejumlah besar protein yang dapat memenuhi kebutuhan protein tubuh. Protein secara umum dapat berfungsi untuk meningkatkan kesehatan tubuh seseorang. Ini terjadi karena protein merupakan komponen yang penting dalam metabolisme tubuh manusia. Selain untuk perbaikan dan pembangunan jaringan tubuh, protein juga berperan dalam produksi antibodi yang akan melindungi tubuh dari infeksi sehingga memperkuat sistem kekebalan tubuh. Beberapa ahli gizi bahkan berpendapat daging menjadi sumber protein yang paling baik karena daging mengandung semua asam amino esensial.

Di dalam mengkonsumsi daging baik daging sapi, kerbau, burung, ayam dan sebagainya tentunya harus diketahui tingkat kehalalannya. Walaupun daging tersebut halal untuk kita konsumsi namun apabila proses pengolahannya tidak dilakukan dengan cara halal maka daging tersebut dikategorikan makanan yang haram dan dilarang untuk di makan, misalnya diawali dari proses dari mana hewan itu diperoleh, apakah dari hasil mencuri, berburu, ataukah hasil beternak, apakah proses penyembelihannya sudah sesuai dengan syariat Islam ataukah belum, apakah daging tersebut dari proses penjualannya tercampur dengan daging babi atau tidak.

Dengan adanya sertifikasi penyembelihan halal yang dikeluarkan oleh Majelis Ulama Indonesia (MUI) terdapat beberapa urgensi. Dari segi konsumen, yaitu adanya jaminan bahwa ayam hasil penyembelihan Rumah Pemotongan Ayam (RPA) yang bersertifikat adalah

al-ạ̣kān Vol. 5, Nomor 1, 2020 
halal dan baik. Dari segi RPA, yaitu adanya kepercayaan bahwa ayam hasil sembelihan RPA yang bersertifikat sesuai dengan Syari'at Islam. Dari segi pemerintahan, yaitu adanya kepedulian pemerintah terhadap konsumsi masyarakat yang sesuai dengan aturan Islam. Pemotongan ayam di Desa kertawinagun sebagian besar masih dilakukan secara tradisional dan sarana yang dimiliki masih terbatas, sehingga menghasilkan karkas ayam yang bermutu rendah. Karkas ayam adalah bobot tubuh ayam setelah dipotong dikurangi kepala, kaki, darah, bulu serta organ dalam (Kosmetik 2011).

Keberagaman dan banyaknya pedagang eceran ayam potong merupakan sebagian mata pencaharian masyarakat Desa Kertawinangun yang dalam hal ini proses penyembelihannya masih dirasakan kurang memenuhi syariat Islam, misalnya penyembelihan ayam dilakukan oleh ibu-ibu, disembelih tidak dipegang atau dibantu oleh orang lain, disembelih tidak di tempat yang layak sehingga darahnya kemana mana, orang yang menyembelih tidak melaksanakan sholat dan lain sebagainya.

Dari latar belakang di atas, peneliti tertarik untuk mengamati secara langsung kegiatan proses pemotongan atau penyembelihan ayam yang dilakukan di Desa Kertawinangun sudah sesuai dengan ketentuan yang telah ditetapkan oleh Majelis Ulama Indonesia atau sebaliknya. Dengan demikian, penelitian ini merumuskan permasalahan sebagai berikut, yaitu pertama, bagaimana proses pelaksanaan penyembelihan ayam potong di Desa Kertawinangun? Dan kedua, bagaimana proses penyembelihan ayam potong yang sesuai dengan standarisasi MUI?

\section{Landasan Teori dan Tinjauan Pustaka}

Kajian pustaka ini pada intinya adalah mendapatkan gambaran tentang kajian/ penelitian yang sudah pernah dilakukan di seputar masalah yang diteliti, sehingga terlihat jelas bahwa kajian atau penelitian yang akan dilakukan tidak merupakan pengulangan atau duplikasi dari kajian/penelitian yang telah ada. Hingga saat ini penulis belum menemukan penelitian yang membahas tentang sertifikasi penyembelihan halal pada RPA.Adapun penelitian yang membahas tentang penyembelihan adalah pertama, Rony $\mathrm{H}$. dan Etwin F. dalam "Analisis Model Kehalalan Proses Potong Ayam di Rumah Potong Ayam (RPA) di Samarinda". Hasil penelitian ini menyatakan bahwa pemotongan ayam di Pasar Pagi dan Pasar Segiri semuanya bersifat illegal dan tidak tersertifikasi halal oleh LPPOM MUI Samarinda. Melalui metode kualitatif yang digunakan dalam menganalisis masalah tersebut, maka dalam kesimpulannya ayam hasil pemotongan di Pasar Pagi dan Pasar Pagi tidak dapat dikatakan tidah halal, karena semua syarat pemotongan cukup dilakukan, hanya saja petugas maupun rumah potong tidak tersertifikasi halal MUI (H, Rony; Etwin 2017).

Dan kedua, Tian Nur Ma'rifat dan Arief Rahmawan dalam “Penerapan Rantai Pasok Halal pada Komoditas Daging Ayam di Kabupaten Ponorogo". Hasil penelitian ini menguraikan 
rantai pasok daging ayam dari hulu (peternak ayam) hingga hilir (end customer). Beberapa hal yang menjadi titik kritis penerapan prinsip halal pada rantai pasok daging ayam di Kabupaten Ponorogo dalam penerapan prinsip halal antara lain tata cara penyembelihan ayam, petugas penyembelih, alat penyembelihan, prosedur tertulis untuk aktivitas kritis, penanganan selama penyimpanan dan pelabelan (Ma'rifat 2017).

Dari kedua topik penelitian yang telah dipaparkan di atas, ternyata belum ada tinjauan secara khusus dan komprehensif yang memaparkan standarisasi proses penyembelihan hewan yang sesuai dengan fatwa MUI. Oleh karena itu, diharapkan penelitian ini mampu mengungkapkan, mendeskripsikan, dan menganalisis lebih jauh sesuai dengan perkembangan saat ini. Di sinilah letak perbedaan studi ini dengan studi-studi yang telah dilakukan sebelumnya.

\section{Metode Penelitian}

\section{Sumber Data}

Pertimbangan dalam memilih masalah penelitian adalah ketersediaan sumber data. Suharsimi Arikunto menjelaskan bahwa yang dimaksud dengan sumber data dalam penelitian adalah subjek dari mana data dapat diperoleh (Suharsimi 2010). Apabila peneliti menggunakan wawancara dalam pengumpulan datanya, maka sumber data disebut responden, yaitu orang yang merespon atau menjawab pertanyaan peneliti, baik pertanyaan tertulis maupun lisan.

Dalam penggunaan teknik observasi, maka sumber datanya bisa berupa benda, gerak atau proses tertentu. Contohnya penelitian yang mengamati pemotongan ayam, maka sumber datanya adalah pemilik jasa pemotongan ayam, sedangkan objek penelitiannya adalah pertumbuhan layanan jasa.Pada penelitian ini yang menjadi responden adalah pemilik jasa dan penjual ayam potong di Desa Kertawinangun Kecamatan Kedawung Kabupaten Cirebon. Sumber data dapat berupa benda bergerak, manusia, tempat dan sebagainya.

Berikut uraian lebih lanjut tentang sumber data dalam penelitian yang dimaksud, yaitu:

a. Data Primer yaitu data yang diambil dari lapangan langsung melalui proses observasi atau pengamatan dan wawancara, baik secara terstruktur maupun tidak terstruktur.

b. Data Sekunder yaitu data yang diambil dari pemerintahan Desa Kertawinangun yang berkaitan dengan jumlah pedagang ayam potong, jumlah pedagang ecer ayam potong di Desa Kertawinagun. 
c. Data Tersier yaitu merupakan data pendukung berupa Fatwa MUI tentang standarisasi pemotongan hewan, jurnal dan buku-buku yang berkaitan dengan standarisasi hewan potong.

\section{Teknik Pengumpulan Data}

Teknik pengumpulan data yaitu cara yang digunakan dalam rangka mencari datadata yang diperlukan. Pengumpulan data dalam penelitian ini menggunakan beberapa metode dengan tujuan agar data yang diperoleh valid, sehingga dapat mempermudah penulis dalam menyelesaikan penelitian ini, teknik pengumpulan data antara lain:

a. Pengumpulan data lapangan melalui wawancara mendalam, merupakan suatu cara mengumpulkan data atau informasi dengan cara langsung bertatap muka dengan informan, yaitu petugas RPA dan MUI bagian sertifikasi.

b. Observasi yaitu pengamatan langsung sebagai usaha pengumpulan data yang dilakukan secara sistematis tentang tingkah laku dan percakapan. Penulis mengikuti secara langsung proses penyembelihan di rumah potong ayam.

c. Dokumentasi yaitu peneliti menyelidiki benda-benda seperti buku-buku, dokumen, peraturan-peraturan dan sebagainya.

d. Pengumpulan data kepustakaan. Data dalam kepustakaan dikumpulkan dengan cara membaca, mengklasifikasi bagian-bagian yang relevan dengan bab pembahasan yang selanjutnya mendeskripsikan data-data tersebut, artinya semua data yang dikumpulkan dipaparkan sedemikian rupa agar lebih mudah dalam menganalisis data tersebut.

\section{Teknik Analisis Data}

Setelah memperoleh data yang dibutuhkan dalam penelitian ini, langkah selanjutnya yang harus dilakukan adalah analisis data. Sebagaimana telah dinyatakan pada bahasan sebelumnya, ada dua jenis metode analisis data yaitu deskriptif dan verikatif. Deskriptif untuk menjabarkan atau menganalisis data mengenai pelaksanaan penyembelihan di rumah potong ayam yang belum bersertifikasi di Desa Kertawinangun.Dan bersifat verikatif untuk mengkaji data mengenai sertifikasi penyembelihan halal dari sisi urgensi adanya sertifikasi halal pada pedagang ecer potong ayam di Desa Kertawinangun.

\section{Pembahasan Dan Diskusi}

\section{Proses Pelaksanaan Penyembelihan Ayam Potong di Desa Kertawinangun}

Berdasarkan wawancara dengan Bapak Sholeh selaku Kaur Kesra Desa Kertawinangun, Kecamatan Kedawung Kabupaten Cirebon terdapat 18 (delapan belas) pedagang ayam 
keliling, 9 (sembilan) pedagang ayam eceran, dan 6 (enam) pemilik bandar ayam yang sekaligus melakukan pemotongan ayam. Namun dalam melakukan proses penyembelihan ayam, ternyata satu sama lain terkadang mempunyai cara dan pengolahan yang berbeda, kendatipun secara keseluruhan tetap terdapat persamaan diantaranya.

Persamaan tentang cara pemotongan dan tahapan pengolahan ayam potong, dapat dikelompokan dalam tiga tahapan yang dilalui untuk mendapatkan daging ayam yang siap dipasarkan kepada konsumen, yaitu:

\section{Tahapan dalam Persiapan Ayam}

Pemotongan ayam yang ada di Desa Kertawinangun dilakukan oleh pedagang ayam keliling, pedagang ayam eceran, dan pemilik bandar ayam yang sekaligus melakukan pemotongan ayam yang dilakukan sendiri. Khusus bagi pedagang ayam keliling dan pedagang ayam eceran, mereka memperoleh ayam-ayam yang akan dipotong dari pemasok bandar ayam potong dengan sistem kemitraan. Bandar-bandar ayam potong tersebut, yaitu PD. Putera Surya H. Idris, PD. H. Ratam, PD. H. Misya, PD. H. Dalip, PD. H. Nana, dan PD. H. Bahrul. Sistem pembeliannya juga tidak secara langsung datang ke lokasi peternakan ayam, melainkan pedagang ayam kelililing dan pedagang ayam eceran yang akan membeli ayam akan mentransfer sejumlah uang sesuai dengan harga ayam yang dibeli ke nomor rekening pihak bandar ayam setempat, menurut Bapak Abdurrahman selaku Pamong Desa Kertawinangun.

Kemudian pihak bandar ayam akan menghubungi pedagang ayam keliling dan pedagang ayam eceran untuk pengambilan ayamnya di kandang-kandang yang dimiliki oleh bandar ayam tersebut. Pengambilan ayam tidak hanya dilakukan dari satu lokasi saja, namun hal itu tergantung pada kehendak bandar ayam tersebut.Pengambilan ayam dilakukan setiap hari pada sore hari, sebelum ayam disembelih pada malam harinya. Ayam yang baru sampai akan ditampung di kandang yang dimiliki oleh pedagang ayam keliling dan pedagang ayam eceran. Ayam yang ditampung di kandang tersebut tidak diberi makan dan minum. Alasannya Bapak Bunai dalam sebuah wawancara mengatakan:

"Ayam yang baru datang itu langsung dimasukkan ke kandang tanpa
diberi makan, karena di tempat sebelumnya sudah diberi makan.Oleh
karena itu jika ayam tersebut dikasih makanan lagi dapat menyebabkan
kotorannya jadi banyak sewaktu disembelih malam harinya".

\section{Tahapan dalam Penyembelihan}

Penyembelihan ayam yang dilakukan oleh pedagang ayam keliling dan pedagang ayam eceran di Desa Kertawingangun masih menggunakan metode tradisional. Tidak ada mesin yang membantu penyembelihan karena penyembelihan hanya menggunakan tangan 
dan pisau yang sederhana, namun di beberapa tempat proses tersebut sudah menggunakan mesin cabut bulu. Jumlah pekerja yang dimilikipun hanya sedikit, meskipun jumlah ayam yang disembelih lumayan banyak, yaitu sekitar 100-150 ekor ayam perharinya. Bahkan jika di bulan-bulan tertentu yang banyak masyarakat setempat melakukan hajatan, maka ayam yang dipotong bisa mencapai 200-250 ekor ayam perharinya.

Penyembelihan yang dilakukan oleh para pedagang ayam keliling dan pedagang ayam eceran biasanya dilakukan oleh seorang pekerja laki-laki yang beragama Islam. Bapak Samsudin selaku pedagang ayam keliling mengatakan:

"Penyembelihan ayam biasanya dilakukan sendiri dengan dibantu oleh pekerja ataupun keluarganya. Hal ini dimaksudkan untuk mengefisienkan waktu, sehingga ayam yang disembelih dapat segera diproses ke proses selanjutnya, seperti pembersihan bulu, pembersihan jeroan, dan sebagainya".

Lain lagi dari penuturan Bapak Mair, dapat diketahui bahwa penyembelihan ayam di rumahnya dilakukan oleh pekerjanya yang sudah mengerti mengenai tata cara penyembelihan ayam. Penyembelihan dimulai sekitar pukul 02.00 WIB sampai dengan sekitar pukul 06.00 WIB.Ayam yang diambil dari kandang langsung disembelih satu persatu di bagian lehernya dengan menggunakan pisau yang tajam dengan membaca basmalah. Kemudian dalam menjelankan proses selanjutnya, ayam yang telah disembelih diletakkan pada sebuah wadah besar dan dipindahkan ke mesin cabut bulu. Jika ada ayam yang belum mati ketika akan dilakukan proses lebih lanjut, maka ayam akan dibiarkan begitu saja sampai ayam tersebut mati dengan sendirinya.

Sedangkan penyembelihan ayam di Bapak Buna'i yang merupkan pedagang keliling di komplek perumahan sekitar Cirebon dilakukan oleh dirinya langsung dengan dibantu oleh istrinya. Bapak Buna'i saat ini berumur 35 tahun dan beragama Islam. Adapun penyembelihan dimulai pada pukul 02.30 WIB sampai dengan selesai, namun biasanya sebelum masuk waktu sholat subuh kata beliau ketika diwawancarai. Dalam proses penyembelihan, Bapak Buna'i masih menerapkan sistem manual dimulai dari pemotongan dengan menggunakan pisau yang tajam dengan membaca basmalah dalam hati, hingga pembersihan bulu-bulu ayam dan pembersihannya.

Berbeda dengan penyembelihan ayam yang dilakukan oleh pedagang ayam keliling di Desa Kertawinangun pada umumnya, meskipun mereka sama-sama menggunakan pisau yang tajam dan membaca basmalah, akan tetapi penyembelihan yang dilakukan Bapak Agung selalu memastikan sampai ayam tersebut benar-benar mati sebelum diproses lebih lanjut. Untuk bagian yang disembelih, bapak Agung mengatakan:

"Bagian leher ayam merupakan bagian yang dipotong, tepatnya pada dua saluran yaitu saluran makanan dan nafas (urat nadinya).Dan setelah itu harus 
dipastikan ayam itu benar-benar mati, karena hal itu ada ketentuan hukumnya, meskipun pihak konsumen tidak tahu tapi kita kelak yang menanggungnya".

Berdasarkan informasi di atas, terdapat pemahaman yang berbeda mengenai tata cara penyembelihan ayam yang dilakukan oleh pedagang di desa Kertawinangun yang tentunya memberikan ketentuan hukum yang berbeda pula.

\section{Tahapan dalam Pengolahan Ayam}

Baik pemotongan ayam yang dilakukan oleh pedagang ayam kelililing, pedagang ayam eceran, dan pemilik bandar ayam yang sekaligus melakukan pemotongan ayam, ternyata dilakukan proses yang sama setelah ayam tersebut disembelih. Tahapan awal dalam hal ini yaitu ayam yang telah dipotong dimasukkan ke dalam air panas dengan suhu sekitar 50 으- 60 으. Hal tersebut berdasarkan pernyataan dari pemilik ketiga jenis pedagang ayam di atas. Lebih lanjut, Bapak H. Idris mengatakan bahwa air yang digunakan untuk merendam ayam sehabis dipotong adalah air panas, yang kadar panasnya tidak sampai mendidih. Dalam prosesnya, ayam tersebut dimasukkan ke panci besar yang mampu menampung tiga sampai lima ekor ayam dalam sekali rendaman dengan air panas. Ayam-ayam tersebut direndam kurang lebih selama lima menit, baik ayam dengan ukuran yang besar, maupun yang kecil. Setelah itu, ayam tersebut dimasukkan ke dalam mesin pencabut bulu untuk menghilangkan bulu-bulu ayam hingga bersih, selanjutnya dilakukan proses pembelahan untuk memisahkan daging dengan bagian jeroan dan kotoran ayam.

Untuk efektifitas dan efisiensi waktu, para pedagang ayam kelililing, pedagang ayam eceran, dan pemilik bandar ayam melakukan pemotongan ayam, sekaligus menggunakan mesin pencabut bulu ayam. Akan tetapi juga ada perbedaan pada daging ayam yang bulunya dicabut secara manual dengan daging ayam yang bulunya dicabut menggunakan mesin, Bapak Buna'i mengatakan:

"Ada perbedaan antara proses pencabutan bulu ayam yang melalui
mesin dengan cara manual. Bagi ayam yang bulunya dicabut dengan
tangan, jika dilihat dari segi kualitas jelas lebih bagus karena jika
dicabut dengan mesin terkadang tulang ayamnya menjadi patah-patah,
berbeda dengan hasil yang diperoleh secara manual.Tapi kalau tidak
menggunakan mesin, dalam prosesnya memakan waktu yang lama."

Proses selanjutnya setelah pencabutan bulu ayam adalah pengeluaran jeroan dan pemotongan ayam ke dalam bagian-bagian yang lebih kecil. Proses pengeluaran jeroan dilakukan di tempat itu juga, yang tidak terpisah dari tempat penyembelihan, perendaman dan pencabutan bulu.Biasanya, proses pengeluaran jeroan dilakukan di lantai, di samping tempat penyembelihannya, mengingat keterbatasan lahan dan jumlah tenaga kerja. Setelah

al-ạ̣kām Vol. 5, Nomor 1, 2020 
ayam tersebut selesai dikeluarkan jeroannya, kemudian ayam dicuci di tempat pencucian yang lokasinya masih sama engan menggunakan air bersih sebanyak dua kali.

Pekerja yang bekerja di PD. Putera Surya H. Idris berjumlah dua orang, sehingga semua proses mulai dari penyembelihan, perendaman, pencabutan bulu, pengeluaran jeroan, hingga pencucian dilakukan oleh kedua orang tersebut. Dengan pengalaman dan lamanya bekerja, proses yang dilakukan dari penyembelihan hingga pemotongan daging ayam dilakukan dengan cepat, sehingga terkadang kurang memperhatikan kebersihan ayam tersebut.

Proses diatas tentu berbeda dengan yang dilakukan oleh pedagang ayam kelililing dan pedagang ayam eceran. Ini karena ayam yang diproses oleh pedagang keliling dan pedagang ayam eceran berjumlah lebih sedikit, sehingga sendirisehingga proses penyembelihan hingga pemotongan daging ayam dilakukan sendiri. Hal ini terlihat dari mulai perendaman, pencabutan bulu, pengeluaran jeroan hingga pencucian dilakukan lebih hati-hati sehingga daging ayam dihasilkan lebih bersih.

Setelah ayam-ayam yang telah diproses itu bersih, kemudian dilanjutkan proses pemotongan, dan berakhir pada kegiatan pemasaran ayam. Tahap inipun dilakukan pada satu lokasi yang sama dengan tahap-tahap sebelumnya. Hal yang membedakan adalah meja tempat pemotongannya disediakan secara khusus. Mengenai hal tersebut, Bapak Agung mengatakan, bahwa tempat pemotongannya itu sebesar meja makan, yang letaknya tidak jauh dari proses sebelumnya. Adanya keterbatasan lahan justru lebih dapat mengefisensikan waktu. Begitu pula alasan yang dikemukakan oleh pemilik PD. Putera Surya $\mathrm{H}$. Idris, lahan yang sempit menjadi alasan mengapa lokasi penyembelihan dan pengolahan ayam dilakukan pada satu lokasi.

Setelah proses persiapan ayam sebelum disembelih, penyembelihan ayam dan pengolahan ayam setelah disembelih selesai dilakukan, daging ayam tersebut dijual kepada konsumen di sekitar wilayah Cirebon, dan bagi bandar ayam besar biasanya daging ayam tersebut disimpan di rumah potong ayamnya sebelum dijual atau diambil oleh para pedagang keliling dan eceran.

Bapak Idris berkata bahwa penjualan yang dilakukan oleh bandar ayam besar di Desa Kertawinangun dilakukan melalui tiga tahap, yaitu:

1) Memasok ayam potong ke beberapa penjual, baik penjual di pasar-pasar tradisional maupun penjual yang memasarkan langsung secara keliling.

2) Menerima pesanan ayam potong bagi warga sekitar.

3) Menjual ayam potong bagi konsumen yang ingin membeli sendiri di rumah potong ayam sekalipun tanpa pemesanan terlebih dahulu.

Dalam pemasokan ayam bagi penjual di pasar-pasar tradisional, para pemilik bandar ayam akan mengirimnya ke tempat-tempat penjual setelah ayam siap. Pengiriman ayam 
biasanya dilakukan dengan menggunakan sepeda motor dengan alat seadanya, namun untuk pembeli dengan cara pemesanan biasanya pembeli akan datang sendiri untuk mengambil ayam sesuai pesanannya.

Oleh karena itu, bagi para pemilik bandar ayam yang mengembangkan jasa pemotongan ayam, biasanya memiliki tempat penyimpanan ayam, meskipun dalam jumlah yang sedikit karena jarang digunakan.Tempat penyimpanan tersebut berupa freezer, yang difungsikan untuk menyimpan daging ayam yang tidak terjual dan tidak terkirim atau ayam sisa sehingga dapat dijual pada keesokan harinya, pungkas Bapak Idris. Freezer yang ada di PD. Putera Surya H. Idris misalnya, hanya digunakan ketika ada ayam sisa pada hari penyembelihan tersebut. Hal ini dimaksudkan agar daging-daging ayam tersebut tidak cepat membusuk.

\section{Proses Penyembelihan Ayam Potong yang Sesuai dengan Standarisasi MUI}

Penyembelihan dan pengolahan ayam di pedagang ayam kelililing, pedagang ayam eceran, dan pemilik bandar ayam yang sekaligus melakukan pemotongan di Desa Kertawinangun masih menggunakan cara yang tradisional, hanya saja di beberapa tempat sudah menggunakan mesin pencabut bulu. Namun secara keseluruhannya, dapat dikatakan bahwa peralatan yang digunakan juga masih tergolong tradisional.

Penyembelihan dan pengolahan ayam di Desa Kertawinangun merupakan usaha turunan dari orang tuanya yang telah disesuaikan dengan perkembangan zaman. Usaha pemotongan ayam tersebut sudah dilakukan sejak lama meskipun dengan peralatan sederhana dan banyaknya permintaan akan daging ayam. Seiring dengan perjalanan waktu, usaha yang awalnya sebatas usaha rumahan dengan jumlah permintaan yang rendah, kemudian berkembang menjadi usaha dengan jumlah permintaan yang tinggi.Namun tidak sedikit pula, perkembangan waktupun menggerus beberapa usaha tersebut, sehingga di desa Kertawinangun sendiri terdapat beberapa usaha yang gulung tikar.

Proses pertama yang dilakukan oleh pedagang ayam kelililing, pedagang ayam eceran, dan pemilik bandar ayam yang sekaligus melakukan pemotongan di Desa Kertawinangun yaitu persiapan ayam. Bagi pedagang ayam kelililing dan pedagang ayam eceran yang mengambil ayam-ayam dari bandar besar, dalam prosesnya, ayam yang telah diambil dari mitra kerjasama, ditempatkan pada kandang tersendiri tanpa diberi makan ataupun minum. Hal ini dimaksudkan agar tidak berpengaruh pada daging ayam tersebut setelah disembelih dan diolah untuk kemudian di pasarkan ke konsumen.

Alasan lain yang biasa diterapkan oleh pedagang ayam kelililing dan pedagang ayam eceran yang mengambil ayam-ayam dari bandar besar, yaitu ayam sebelum disembelih sebaiknya diistirahatkan dahulu selama 6-12 jam. Pengistirahatan ini dimaksudkan agar ayam-ayam tidak stres, darah dapat keluar sebanyak mungkin, dan jumlah kotorannya tidak

al-ạ̣kām Vol. 5, Nomor 1, 2020 
terlalu banyak.

Proses penyembelihan yang dilakukan oleh pedagang ayam kelililing, pedagang ayam eceran, dan pemilik bandar ayam yang sekaligus melakukan pemotongan di Desa Kertawinangun dapat diperinci dalam tahapan sebagai berikut:

a. Bagi pedagang ayam kelililing dan pedagang ayam eceran, pengiriman ayam dilakukan dengan menggunakan mobil bak atau kendaraan tossa menuju tempat yang dituju.

b. Ayam-ayam yang baru saja didatangkan, kemudian ditempatkan di kandang khusus.

c. Pengambilan ayam dari kandang secara satu persatu oleh penyembelih, dan disembelih dengan membaca basmallah dalam hati.

d. Penyembelihan ayam dilakukan di bagian leher, yaitu di saluran makan, kerongkongan, dan dua pembulu darahnya dengan menggunakan pisau yang tajam.

Proses selanjutnya setelah ayam-ayam disembelih adalah proses pengolahan. Proses pengolahan ayam terbagi dalam enam tahap, yaitu:

a. Perendaman Ayam yang sudah Disembelih. Ayam yang sudah disembelih, selanjutnya direndam di dalam air panas dengan kisaran suhu sekitar 50 으-60ㄷ selama kurang lebih 5 menit dengan menggunakan wadah panci besar dengan kapasitas 3-5 ekor ayam dalam sekali rendaman.

b. Pencabutan Bulu-bulu Ayam. Setelah ayam direndam selama kurang lebih 5 menit, tahap selanjutnya adalah pencabutan bulu ayam dengan menggunakan mesin pencabut bulu ayam.

c. Pengeluaran Jeroan Ayam. Setelah ayam bersih dari bulu, tahap selanjutnya adalah mengeluarkan bagian jeroan ayam. Bagian jeroan yang sudah dikeluarkan akan diolah lebih lanjut karena akan dipasarkan, dan sebagaian lagi dibuang atau dimanfaatkan untuk pakan ikan lele karena tidak layak jual.

d. Pencucian Daging Ayam. Ayam yang sudah dikeluarkan jeroannya akan dicuci sebanyak dua kali pencucian pada wadah atau tempat yang sudah disediakan, sehingga daging ayam tersebut benar-benar telah bersih.

e. Pemotongan Daging Ayam. Daging ayam yang sudah dibersihkan kemudian dipotong di atas meja pemotongan yang khusus.Pemotongan dilakukan sesuai dengan pesanan dan kebutuhan.Namun apabila daging ayam dipasok ke pedagang di pasar-pasar tradisional, maka daging tidak dipotong dan dibiarkan utuh tanpa jeroan.

f. Pengemasan Potongan Daging Ayam. Pengemasan dilakukan di tempat pemotongan dengan menggunakan wadah plastik. Sedangkan untuk daging ayam yang dikirim ke pedagang di pasar tradisional tidak dimasukkan plastik dan langsung dimasukkan ke dalam keranjang yang telah dipasang di motor. 
Dalam ketentuan $\mathrm{MUI}$, ternyata ditemukan fatwa yang membahas proses penyembelihan hingga proses-proses berikutnya yang tertuang dalam fatwa MUI No. 12 Tahun 2009 tentang Standar Sertifikasi Penyembelihan Halal. Fatwa ini menyatakan bahwa:

a. Standar Hewan yang Disembelih

1) Hewan yang disembelih adalah hewan yang boleh dimakan.

2) Hewan dalam keadaan hidup ketika disembelih.

3) Kondisi hewan harus memenuhi standar kesehatan hewan yang ditetapkan oleh lembaga yang memiliki kewenangan.

b. Standar Penyembelih

1) Beragama Islam dan sudah akil baligh.

2) Memahami tata cara penyembelihan secara syar'i.

3) Memiliki keahlian dalam penyembelihan.

c. Standar Alat Penyembelihan

1) Alat penyembelihan harus tajam.

2) Alat dimaksud bukan kuku, gigi/taring, atau tulang.

d. Standar Proses Penyembelihan

1) Penyembelihan dilaksanakan dengan niat menyembelih dan menyebut Asma Allah.

2) Penyembelihan dilakukan dengan mengalirkan darah melalui pemotongan saluran makan (mari'/esophagus), saluran pernafasan/kerongkongan (hulqum/ trakea), dan dua pembulu darah (wadajain/vena jugularis dan arteri carotids).

3) Penyembelihan dilakukan dengan satu kali dan secara cepat.

4) Memastikan adanya aliran darah dan/atau gerakan hewan sebagai tanda hidupnya hewan (hayah mustaqirah).

5) Memastikan matinya hewan disebabkan oleh penyembelihan tersebut.

e. Standar Pengolahan, Penyimpanan, dan Pengiriman

1) Pengolahan dilakukan setelah hewan dalam keadaan mati oleh sebab penyembelihan.

2) Hewan yang gagal penyembelihan harus dipisahkan.

3) Penyimpanan dilakukan secara terpisah antara yang halal dan non-halal.

4) Dalam proses pengiriman daging, harus ada informasi dan jaminan mengenai setatus kehalalannya, mulai dari penyimpanan (seperti pengepakan dan pemasukan ke dalam kontainer), pengangkutan (seperti pengapalan/shipping), hingga penerimaan (Indonesia 2009).

Dengan melihat ketentuan Fatwa MUI No. 12 Tahun 2009 tentang Standar Sertifikasi Penyembelihan Halal di atas, maka penyembelihan ayam potong di Desa Kertawinangun dapat dikatakan sudah sesuai ketentuan Syari'at Islam. Hal ini sesuai hasil observasi lapangan

al-aḥ̂ām vol. 5, Nomor 1, 2020 
yang dilakukan oleh peneliti pada pedagang ayam kelililing, pedagang ayam eceran, dan pemilik bandar ayam yang sekaligus melakukan pemotongan di Desa Kertawinangun, dapat dinyatakan bahwa pelaksanaan proses penyembelihan ayam ditujukan kepada ayam-ayam yang masih hidup dengan menggunakan pisau yang tajam tepat di bagian leher ayam sekali goresan dan cepat, sehingga saluran makan, kerongkongan, dan dua pembuluh darahnya terputus. Selain itu, penyembelihan juga dilakukan oleh seorang yang ahli, beragama Islam dan sudah akil baligh, dan membaca basmallah ketika hendak menyembelih. Peneliti juga melakukan observasi secara langsung dan melakukan wawancara kepada pihak terkait, perihal proses selanjutnya setelah ayam-ayam tersebut disembelih. Dalam menjalankan proses setelah penyembelihan, ayam yang telah mati tersebut langsung dikuliti, dipisahkan daging dengan jeroan dan kotoran, dan pemotongan sesuai ukuran pemesanan ataupun untuk daging ayam yang dikirim ke pedagang di pasar tradisional tidak dipotong-potong, namun dibiarkan utuh tanpa jeroan.

\section{Kesimpulan}

Berdasarkan hasil pembahasan di atas, dapat diambil dua kesimpulan, yaitu pertama,cara pemotongan dan tahapan pengolahan ayam potong di Desa Kertawinangun dapat dikelompokan dalam tiga tahapan, yaitu tahapan dalam persiapan ayam, tahapan dalam penyembelihan, dan tahapan dalam pengolahan ayam. Dan kedua, proses penyembelihan yang dilakukan oleh pedagang ayam kelililing, pedagang ayam eceran, dan pemilik bandar ayam yang sekaligus melakukan pemotongan di Desa Kertawinangun dapat diperinci dalam beberapa tahapan, yaitu; (1).Bagi pedagang ayam kelililing dan pedagang ayam eceran, pengiriman ayam dilakukan dengan menggunakan mobil bak atau kendaraan tossa menuju tempat yang dituju. (2). Ayam-ayam yang baru saja didatangkan, kemudian ditempatkan di kandang khusus. (3). Pengambilan ayam dari kandang secara satu persatu oleh penyembelih, dan disembelih dengan membaca basmalah dalam hati. (4). Penyembelihan ayam dilakukan di bagian leher, yaitu di saluran makan, kerongkongan, dan dua pembulu darahnya dengan menggunakan pisau yang tajam.

\section{Daftar Pustaka}

H, Rony; Etwin, F. 2017. "Analisis Model Kehalalan Proses Potong Ayam Di Rumah Potong Ayam (RPA) Di Samarinda." SNITT Politeknik Negeri Balikpapan.

Hadi, Abu Sari Muhammad Abdul. 1997. Hukum Makanan Dan Sembelihan. Bandung: Trigenda Karya. 
Indonesia, Majelis Ulama. 2009. "Fatwa MUI No.12 Tahun 2009.”

Kosmetik, Lembaga Pengkajian Pangan Obat-Obatan dan. 2011. "Indonesia Halal Directory 2011." Jakarta.

Ma'rifat, Tian Nur; Arief Rahmawan. 2017. "Penerapan Rantai Pasok Halal Pada Komoditas Daging Ayam Di Kabupaten Ponorogo." Jurnal Cemara 14, no. 1.

Suharsimi, Arikunto. 2010. Prosedur Penelitian: Suatu Pendekatan Praktek. Jakarta: Rieneka Cipta. 